\title{
Impacts of Freshwater and Seawater Mixing on the Production and Decay of Virioplankton in a Subtropical Estuary
}

\author{
Wei Wei ${ }^{1,2} \cdot$ Nannan Wang ${ }^{1,2} \cdot$ Lanlan Cai $^{2,3} \cdot$ Chuanlun Zhang ${ }^{4} \cdot$ Nianzhi Jiao ${ }^{2,3} \cdot$ Rui Zhang $^{2,3}$
}

Received: 13 November 2018 / Accepted: 13 March 2019 / Published online: 10 April 2019

(C) The Author(s) 2019

\begin{abstract}
Virioplankton is an important component of the aquatic ecosystem and plays multiple ecological and biogeochemical roles. Although the spatial and temporal distributions and dynamics of virioplankton have been well investigated in riverine and marine environments, little is known about the dynamics and environmental controlling mechanisms of virioplankton in estuaries. In this study, viral abundance, production and decay were examined in the Pearl River Estuary (PRE), one of the largest estuaries in China. The influences of freshwater and seawater mixing on viral ecological dynamics were evaluated with several crosstransplant experiments. In PRE, viral abundance, production and decay rates varied from $2.72 \pm 0.09$ to $27.5 \pm 1.07 \times$ $10^{6}$ viruses $\mathrm{ml}^{-1}, 7.98 \pm 2.33$ to $16.27 \pm 2.85 \% \mathrm{~h}^{-1}$ and $0.80 \pm 0.23$ to $3.74 \pm 0.98 \% \mathrm{~h}^{-1}$, respectively. When the riverine and marine microbial community were transferred into simulated brackish water, viral production rates were markedly inhibited by $83.8 \%$ and $47.3 \%$, respectively. The decay of riverine and marine virioplankton was inhibited by $21.1 \%$ and $34.2 \%$, respectively, in simulated brackish water. These results indicate change of estuarine environmental factors significantly alters the dynamics of riverine and marine virioplankton. In addition, the effects of mixing on viral production and decay differed between high- and low-fluorescence viruses. High-fluorescence viruses seemed more resistant to decay than low-fluorescence viruses, whereas the production of marine low-fluorescence viruses seemed more resistant to inhibition than that of marine high-fluorescence viruses. Together, these results provide new insights into the ecological dynamics of virioplankton in estuarine environments.
\end{abstract}

Keywords Pearl River estuary · Freshwater-seawater cross-transplants · Viral production · Viral decay

Electronic supplementary material The online version of this article (https://doi.org/10.1007/s00248-019-01362-2) contains supplementary material, which is available to authorized users.

Nianzhi Jiao

jiao@xmu.edu.cn

$\triangle$ Rui Zhang

ruizhang@xmu.edu.cn

1 College of the Environment and Ecology, Xiamen University, Xiamen 361102, People's Republic of China

2 State Key Laboratory of Marine Environmental Science, Institute of Marine Microbes and Ecospheres, Xiamen University,

Xiamen 361102, People's Republic of China

3 College of Ocean and Earth Sciences, Xiamen University, Xiamen 361102, People's Republic of China

4 Department of Ocean Science and Engineering, Southern University of Science and Technology, Shenzhen 518055, People's Republic of China

\section{Introduction}

Virioplanktons are the most abundant biological particles in the marine environment, with $10^{5}$ to $10^{8}$ particles $\mathrm{ml}^{-1}$ and are typically an order of magnitude more numerous than their hosts such as autotrophic and heterotrophic prokaryotes [1, 2]. During the past 20 years, it has become well known that viruses play important roles in marine microbial food webs [3-6]. Viruses can cause a high rate of microbial mortality by infection $[2,3]$, regulate elemental cycling via "viral shunt" [7, $8]$ and impact the structure of microbial communities by "killing the winner" $[2,9]$. In addition, the elements of viral particles (e.g. carbon, nitrogen and phosphorus) released into the surrounding environment via decay have very important roles in local and global marine biogeochemical cycles $[10,11]$.

The dynamics of virioplankton are mainly regulated by two processes, i.e. production and decay [11]. The process of viral production entails the infection of a host cell by the virus and the subsequent release of progeny virus particles via lysis. Previous studies have shown that viral production is mainly 
related to the abundance and metabolic activity of their hosts [12-14]. In general, viral production in coastal regions and the surface layer is higher than that in open ocean and at depth $[15,16]$. Regarding viral decay, the components of viruses are impacted by complex biotic and abiotic factors, e.g. solar radiation, temperature, adsorption to organic or inorganic particles, and extracellular enzymes and ultimately degrade and become part of the dissolved organic matter (DOM) [17-21]. Generally, the viral decay rate in eutrophic waters is higher than that in oligotrophic environments [22-25]. The balance of viral production and decay determines the biomass, population size and community composition of virioplankton and impacts virus-host interactions, thereby playing important roles in the microbial food web and biogeochemical cycles $[3,5,6,11]$.

An estuary is a special aquatic ecosystem that mainly consists of three regions: an inlet area, characterised as a freshwater environment; an offshore area dominated by seawater; and a brackish water region formed by the mixing of freshwater and seawater. Due to the dual effects of runoff and tidal flow, an estuary is a complex and multivariate aquatic environment, and it serves as a model ecosystem for studying the dynamics of microbial ecology and their environmental controls. Previous studies have shown that variations of temperature, salinity, organic carbon and nutrients in the estuarine environment impact the spatiotemporal distribution, activity, diversity and community structure of bacterioplankton (e.g. [26-28]). However, there are only a few studies on the ecological characteristics of virioplankton in the estuarine environment [29-33]. In particular, the factors impacting the population dynamics (such as production and decay) of estuarine virioplankton are unclear. Several questions remain unanswered; for example, how does the constant mixing of freshwater and seawater in an estuary affect the production and decay of viruses and therefore virus population size? Do marine and freshwater viruses show similar ecological behaviours at mixing areas? As virioplankton are important members of estuarine ecosystem, investigation of the above questions can improve our understanding of microbial food webs and biogeochemical cycling in estuaries.

Pearl River Estuary (PRE), the second largest estuary in China, is an important area of freshwater that flows into the South China Sea. The total area of PRE is ca. $2600 \mathrm{~km}^{2}$, and the average annual runoff is ca. $3200 \times 10^{8} \mathrm{~m}^{3} \mathrm{a}^{-1}$. A large volume of freshwater is transported from upstream rivers to the PRE annually. The intensive mixing of freshwater and seawater results in highly variable environmental conditions in the PRE, establishing clear environmental gradients of salinity, DOC, nutrient concentrations and other factors. In the PRE region, limited studies have shown that viral abundance is related to the dynamics of bacterioplankton, which are affected by environmental factors [34-36]. However, the effect of freshwater-seawater mixing with changes in environmental factors on viral population dynamics generally remains unknown. Therefore, the objectives of present study were (1) to investigate the ecological dynamics of virioplankton in representative areas of PRE and (2) to explore the effect of freshwater-seawater mixing on viral dynamics through a cross-transplant experiment.

\section{Materials and Methods}

\section{Study Site and Sampling}

Three representative stations were sampled in the PRE in the summer (July): one in a freshwater region (station A: $22.8^{\circ} \mathrm{N}$, $113.6^{\circ} \mathrm{E}$ ), one in a brackish water region (station B: $22.3^{\circ} \mathrm{N}$, $113.7^{\circ} \mathrm{E}$ ) and one in seawater region (station $\mathrm{C}: 21.2^{\circ} \mathrm{N}$, $113.9^{\circ}$ E) (Fig. 1). At each station, water samples were collected with acid-cleaned polycarbonate bottles from the surface (ca. $1 \mathrm{~m}$ depth) and then pre-filtered with $20 \mu \mathrm{m}$ mesh filters to remove large particles and zooplankton. The prefiltered water was used for determinations of picoplankton and virioplankton abundances and the subsequent viral production and decay experiment. A multi-parameter controller (U-50, Horiba, Japan) was used to obtain environmental data on temperature, salinity, turbidity, $\mathrm{pH}$, dissolved oxygen (DO) and oxidation-reduction potential (ORP) at each station.

\section{Determination of Picoplankton and Virioplankton Abundances}

Subsamples $(2 \mathrm{ml})$ were fixed with glutaraldehyde $(0.5 \%$ final concentration), incubated at $4{ }^{\circ} \mathrm{C}$ for $15 \mathrm{~min}$ in the dark, flash frozen in liquid nitrogen and then stored at $-80^{\circ} \mathrm{C}$ [37]. With scatter diagrams of side scatter vs. red fluorescence and orange fluorescence vs. red fluorescence, the abundances of picoeukaryotes, Synechococcus and Prochlorococcus were directly determined by flow cytometry (Epics Altra II, Beckman Coulter, USA) [38, 39]. The samples for heterotrophic bacterial counting were stained with $1.0 \times 10^{-4} \mathrm{SYBR}$ Green I $(v / v$, final concentration, Molecular Probes), incubated for $15 \mathrm{~min}$ in the dark and analysed by flow cytometry with scatter diagrams of side scatter vs. green fluorescence and red fluorescence vs. green fluorescence $[38,39]$. To obtain viral abundance, the samples were diluted with Tris-EDTA buffer $\left(\mathrm{pH} 8.0\right.$; Sigma), stained with $5.0 \times 10^{-5} \mathrm{SYBR}$ Green I $(v / v$, final concentration, Molecular Probes) and then incubated at $80{ }^{\circ} \mathrm{C}$ for $10 \mathrm{~min}$ in a thermostat water bath (DKB-501A, Shanghai Jinghong, China); abundance was then determined by flow cytometry [40, 41]. Data analyses were performed with FCS Express V3 software (De Novo Software, http:// www.denovosoftware.com/). 


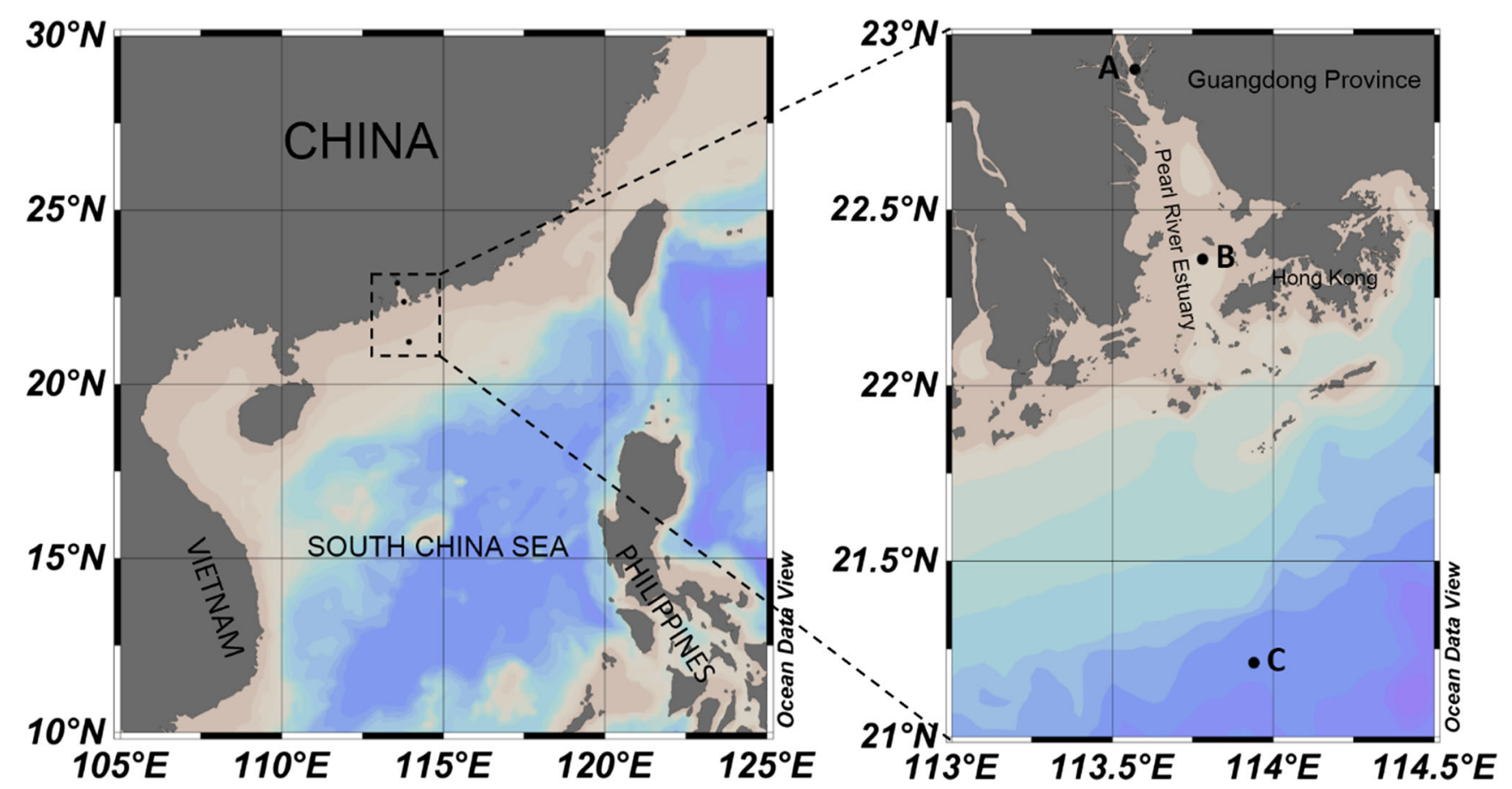

Fig. 1 Map of the sampling stations in the Pearl River Estuary, South China Sea, China. The map was generated using Ocean Data View 4 software (https://odv.awi.de/)

\section{Lytic Viral Production Experiment}

Lytic viral production rates were determined by using a reduction and reoccurrence assay according to Winget et al. [42] and Weinbauer et al. [43]. The 20- $\mu \mathrm{m}$ mesh and $3-\mu \mathrm{m}$ filter pre-filtered samples $(600 \mathrm{ml})$ were filtered by tangential flow filtration (TFF) with a $0.22-\mu \mathrm{m}$ PVDF cartridge (Labscale, Millipore) to obtain the microbial concentrate and filtrate. Then, the filtrate was further ultrafiltered by $30 \mathrm{KD}$ polysulfone cartridge (Labscale, Millipore) and TFF to obtain the viral concentrate and virus-free filtrate. Finally, the microbial concentrate $(50 \mathrm{ml})$ and virus-free water $(250 \mathrm{ml})$ were mixed, and $150 \mathrm{ml}$ samples were incubated in $50-\mathrm{ml}$ aseptic tubes (in triplicate) (Sigma, USA) at in situ temperature in dry bath incubators (MK-20, Hangzhou Allsheng, China) under dark conditions [16].

Subsamples $(1 \mathrm{ml})$ were collected at time 0 and every $3 \mathrm{~h}$ over $12 \mathrm{~h}$ of incubation. The abundances of viruses were detected at each time point by flow cytometry (Fig. $\mathrm{S} 1$ ). The lytic viral production rate (viruses $\mathrm{ml}^{-1} \mathrm{~h}^{-1}$ ) was estimated by the viral accumulation in each $12 \mathrm{~h}$ incubation (e.g. Fig. S2) [44] and was calculated using the VIPCAL (http://www.univie.ac.at/nuhag-php/vipcal/) program [45].

The amount of prokaryotic death $(\triangle \mathrm{PA})$ was determined from the reduction of prokaryotic abundance in the viral production experiment. The formula is as follows:

$\Delta \mathrm{PA}=\left[\left(\mathrm{PA}_{\max 1}-\mathrm{PA}_{\min 1}\right) /\left(t_{\min 1}-t_{\max 1}\right)+\cdots+\left(\mathrm{PA}_{\max n}-\mathrm{PA}_{\min n}\right) /\left(t_{\min n}-t_{\max n}\right)\right] / n$

where $\mathrm{PA}_{\max n}$ and $\mathrm{PA}_{\min n}$ represent the maximum and minimum prokaryotic abundance, respectively, at the $n$th peak of the prokaryotic abundance curve in the viral production experiment, and $t_{\max n}$ and $t_{\min n}$ are the corresponding culture times.

Then, the burst size (BS) is defined as follows:

$\mathrm{BS}=\mathrm{VP}\left(\right.$ viruses $\left.\mathrm{ml}^{-1} \mathrm{~h}^{-1}\right) / \Delta \mathrm{PA}$
The virus-mediated mortality of prokaryotic bacteria (VMM) is defined as follows:

$\mathrm{VMM}=\Delta \mathrm{PA} / \mathrm{PA}_{0}$

where $\mathrm{PA}_{0}$ represents the prokaryotic abundance at $0 \mathrm{~h}$ in the viral production experiment.

The carbon released by lysis (CRL) is defined as follows:

$\mathrm{CRL}=\Delta \mathrm{PA} \times 12.4 \mathrm{fg}$ 
where $12.4 \mathrm{fg}$ is the carbon content of an average marine prokaryotic bacterium [46].

\section{Viral Decay Experiment}

The virioplankton decay rates were determined with the method of Noble and Furhman [25]. The 20- $\mu \mathrm{m}$ and $3-\mu \mathrm{m}$ prefiltered water samples were filtered through $0.22-\mu \mathrm{m}$ pore size polycarbonate filters to exclude the microbes, protozoa, and large particulate matters. The filtered water $(150 \mathrm{ml})$ was then dispensed into $50-\mathrm{ml}$ aseptic tubes (in triplicate) (Sigma, USA) and incubated in dry bath incubators (MK-20, Hangzhou Allsheng, China) at in situ temperature in the dark.

Subsamples $(1 \mathrm{ml})$ were collected every $3 \mathrm{~h}$ for $12 \mathrm{~h}$, and the viral abundances were determined at each time point by flow cytometry with the method described above (Fig. S3). The viral decay rate was calculated as the slope of the linear fitted curve of the viral abundance (ln-transformed) decline over the $12 \mathrm{~h}$ incubation (e.g. Fig. S4). Multiplying the slope by 100, the decay rate was expressed as a percentage per hour [25].

\section{Experimental Setup of the Freshwater-Seawater Cross-transplants}

As described above, using the TFF system, we obtained the riverine microbial concentrate, riverine viral concentrate and virus-free freshwater for station A and the marine microbial concentrate, marine viral concentrate and virus-free seawater for station C. After preparation of these six components, four treatments were applied in this experiment (Fig. 2): (1) riverine microbial community + virus-free seawater $(\mathrm{FB}+\mathrm{S}),(2)$ riverine viral community + virus-free seawater $(\mathrm{FV}+\mathrm{S})$, (3) marine microbial community + virus-free freshwater $(\mathrm{SB}+\mathrm{F})$ and (4) marine viral community + virus-free freshwater $(\mathrm{SV}+\mathrm{F})$. TFF was widely used in microbial oceanography to obtain bacterial concentrate, viral concentrate and virus-free waters for dilution experiments such as measurement of viral production, viral decay, grazing, etc. [25, 43]. The manipulation influences of TFF on physiological and ecological activity of microorganisms, especially bacterioplankton and virioplankton, were considered to be insignificant [43]. In addition, in order to test whether sample handling/manipulation impact viral decay, we performed experiments with traditional vacuum filtration method [25] and compared to our TFF method. Statistical analysis indicated that there was no significant difference among filtration methods (Fig. S5). To develop a similar environmental condition (e.g. temperature, salinity and $\mathrm{pH}$ ) as station $\mathrm{B}$ in the freshwater-seawater crosstransplants experiments, the volume of each component of the mixture was calculated according to Table S1. Each sample was mixed in a 50-ml aseptic tube (in triplicate) and incubated in a dry bath incubator at the in situ temperature of station $\mathrm{B}$ in the dark for $12 \mathrm{~h}$ to determine the viral production and decay rates.

\section{Statistical Analysis}

In this study, the two-tailed Student's $t$-test was used to determine the statistical significance of each parameter with SPSS 19 software (SPSS Inc., Chicago, IL, USA), and differences were considered significant at a $p$ value $<0.05$.

\section{Results}

\section{Environmental Parameters and Microbial Abundance}

Generally, clear environmental gradients were observed from stations A to C, which is typical for estuarine areas (Fig. 1). The salinity increased significantly from stations A $(0.14)$ to $C$ (36.06), as did $\mathrm{pH}$ and DO. In contrast, the turbidity and ORP generally showed the opposite pattern of salinity (Table S1). The lowest temperature was recorded at station $\mathrm{B}$, where the horizontal mixing of freshwater and seawater may have induced the vertical mixing of cold bottom water with warm surface water.

As the dominant picoplankton group in the PRE, heterotrophic bacteria showed a mean abundance of $2.26 \pm 1.82 \times$ $10^{6} \mathrm{cells} \mathrm{ml}^{-1}$, with abundance markedly decreasing along the estuary A-C axis from $4.33 \pm 0.11 \times 10^{6}$ cells ml $^{-1}$ (station A) to $0.88 \pm 0.09 \times 10^{6}$ cells ml $^{-1}$ (station C). In contrast, the Synechococcus and Prochlorococcus abundances increased from the upstream region, with $4.04 \pm 0.10 \times 10^{4}$ cells ml $^{-1}$ and un-detected, respectively, to the downstream region, with $13.9 \pm 0.92 \times 10^{4}$ cells ml${ }^{-1}$ and $16.1 \pm 0.42 \times 10^{4}$ cells ml $^{-1}$, respectively. Picoeukaryotes had a lower abundance than did either Synechococcus or Prochlorococcus with the highest abundance of $8.97 \pm 0.58 \times 10^{3}$ cells ml $^{-1}$ observed in the upper estuary. Their spatial distribution was similar to that of the heterotrophic bacterioplankton. Viruses displayed trends different from those of bacterioplankton. The maximum viral abundance was obtained for freshwater (station A), at $27.5 \pm$ $1.07 \times 10^{6}$ viruses $\mathrm{ml}^{-1}$, whereas the minimum value was observed for brackish water (station B) and was ca. one order of magnitude lower than the maximum value $(2.72 \pm 0.09 \times$ $10^{6}$ viruses $\mathrm{ml}^{-1}$ ). The abundances of high- and lowfluorescence viruses presented the same trends as total virus abundance (Fig. S6) and were highest at station A, at $2.25 \pm$ $0.15 \times 10^{6}$ viruses $\mathrm{ml}^{-1}$ and $25.3 \pm 1.25 \times 10^{6}$ viruses $\mathrm{ml}^{-1}$, respectively, and lowest at station $\mathrm{B}$, with $0.40 \pm 0.12 \times$ $10^{6}$ viruses $\mathrm{ml}^{-1}$ and $2.33 \pm 0.08 \times 10^{6}$ viruses $\mathrm{ml}^{-1}$, respectively.

\section{Spatial Variations of Lytic Viral Production and Viral Decay Rate}

In the PRE, the mean lytic viral production rate was $12.24 \pm$ $4.15 \% \mathrm{~h}^{-1}\left(1.05 \pm 0.58 \times 10^{6}\right.$ viruses $\left.\mathrm{ml}^{-1} \mathrm{~h}^{-1}\right)$, and the rate 


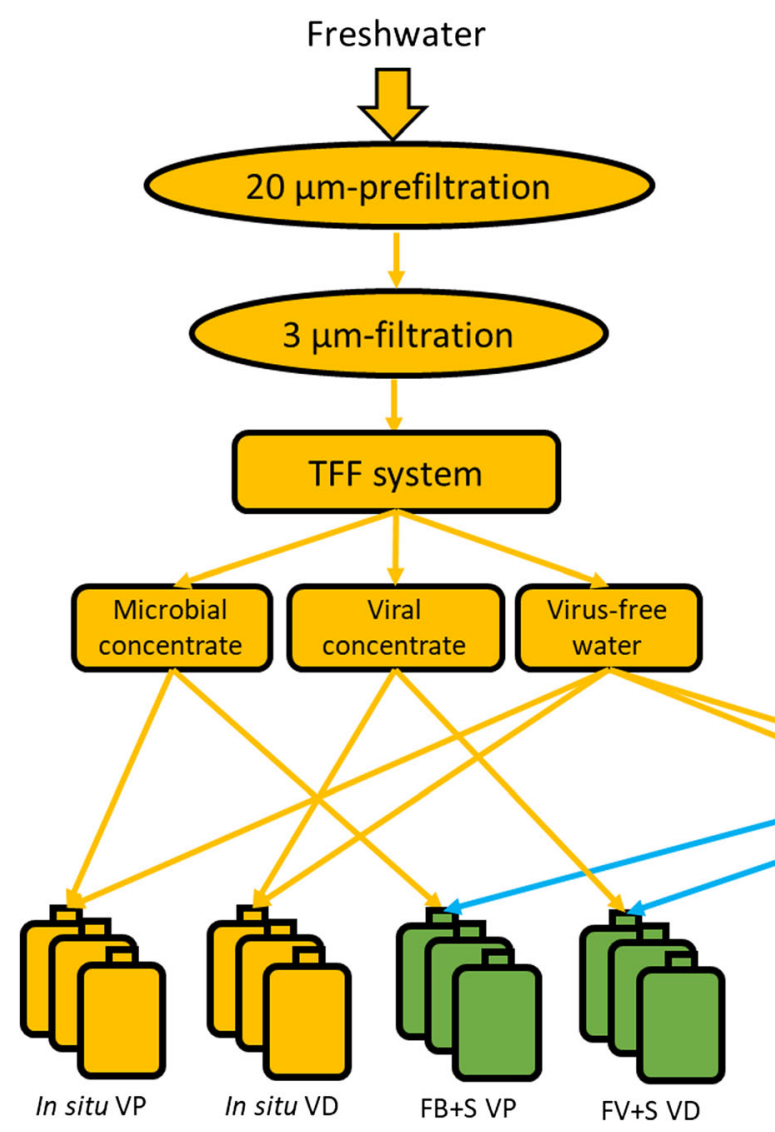

Fig. 2 Schematics of freshwater-seawater cross-transplants for viral production and decay experiments based on TFF systems. Abbreviations represent tangential flow filtration (TFF), the treatment of riverine microbial community + virus-free seawater $(\mathrm{FB}+\mathrm{S})$, the treatment of riverine viral community + virus-free seawater $(\mathrm{FV}+\mathrm{S})$,

increased from $7.98 \pm 2.33 \% \mathrm{~h}^{-1}(2.19 \pm 0.09 \times$ $10^{6}$ viruses $\mathrm{ml}^{-1} \mathrm{~h}^{-1}$ ) at station $\mathrm{A}$ to $16.27 \pm 2.85 \% \mathrm{~h}^{-1}$ $\left(0.62 \pm 0.03 \times 10^{6}\right.$ viruses $\left.\mathrm{ml}^{-1} \mathrm{~h}^{-1}\right)$ at station $\mathrm{C}$ (Table 2$)$. Because the low-fluorescence viruses were the main subgroup of virioplankton, their production rates followed the same trend as that of total viruses and ranged from $7.39 \pm$ $2.34 \% \mathrm{~h}^{-1}\left(1.87 \pm 0.09 \times 10^{6}\right.$ viruses $\left.\mathrm{ml}^{-1} \mathrm{~h}^{-1}\right)$ to $12.47 \pm$ $4.58 \% \mathrm{~h}^{-1}\left(0.35 \pm 0.02 \times 10^{6}\right.$ viruses $\left.\mathrm{ml}^{-1} \mathrm{~h}^{-1}\right)$. The production rates of high-fluorescence viruses were much higher than those of low-fluorescence viruses (e.g. ca. 1.3-fold higher at station A, 2.3-fold higher at station B and 2.0-fold higher at station C). Moreover, the spatial distribution also differed between the high- and low-fluorescence viruses. Although the minimum of high-fluorescence viral production rate was shown in freshwater to be the same as low-fluorescence viral production rate, its maximum was observed in brackish water, with a value of $27.95 \pm 4.66 \% \mathrm{~h}^{-1}(0.11 \pm 0.03 \times$ $10^{6}$ viruses $\left.\mathrm{ml}^{-1} \mathrm{~h}^{-1}\right)$, rather than in seawater.

The viral decay rates presented a significant difference in spatial distribution vs. viral production rates (Table 2). The highest viral decay rate of $3.74 \pm 0.98 \% \mathrm{~h}^{-1}$ was obtained in freshwater, and the lowest value of $0.80 \pm 0.23 \% \mathrm{~h}^{-1}$ was
Seawater

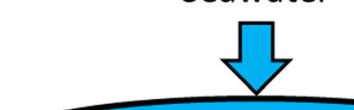

$20 \mu \mathrm{m}$-prefiltration

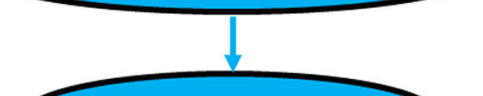

$3 \mu \mathrm{m}$-filtration
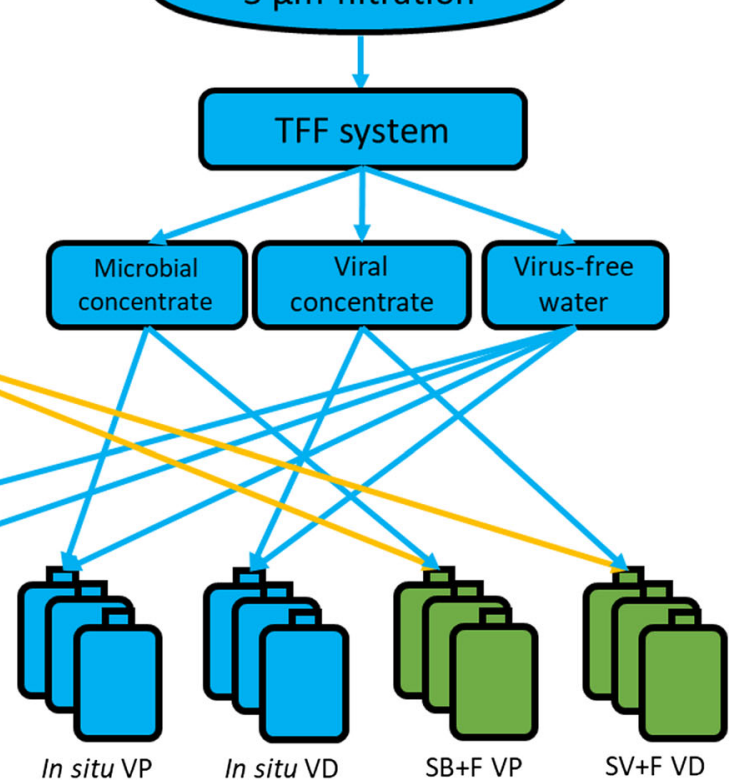

the treatment of marine microbial community + virus-free freshwater $(\mathrm{SB}+\mathrm{F})$, the treatment of marine viral community + virus-free freshwater $(\mathrm{SV}+\mathrm{F})$, viral production experiment $(\mathrm{VP})$ and viral decay experiment (VD)

observed in brackish water. The decay rates of high- and lowfluorescence viruses both followed the pattern of the decay rate of total viruses, with peak values of $4.61 \pm 0.83 \% \mathrm{~h}^{-1}$ and 3.46 $\pm 1.06 \% \mathrm{~h}^{-1}$, respectively, detected in freshwater. The decay rates of high-fluorescence viruses were all higher than those of low-fluorescence viruses, especially in brackish water, with the former subgroup having a ca. 4.5 -fold higher decay rate.

\section{Viral Production and Decay Rates in the Experiment of Freshwater-Seawater Cross-transplants}

In order to further study the effect of natural water mixing in the estuarine environment, i.e. the flow of upstream riverine freshwater and the return of downstream marine seawater into the estuary, on viral dynamics, an experiment with freshwater-seawater cross-transplants was performed.

When freshwater microbes were placed in seawater $(\mathrm{FB}+$ $\mathrm{S}$ treatment), the viral production rate was reduced from 7.98 $\pm 2.33 \% \mathrm{~h}^{-1}$ (station A) to $1.29 \pm 0.20 \% \mathrm{~h}^{-1}(\mathrm{FB}+\mathrm{S}$ ) (Fig. 3). Similarly, when seawater microbes were placed in freshwater ( $\mathrm{SB}+\mathrm{F}$ treatment), the viral production rate was reduced from $16.3 \pm 2.85 \% \mathrm{~h}^{-1}$ (station C) to $8.59 \pm 1.46 \% \mathrm{~h}^{-1}(\mathrm{SB}+\mathrm{F}$ ). 

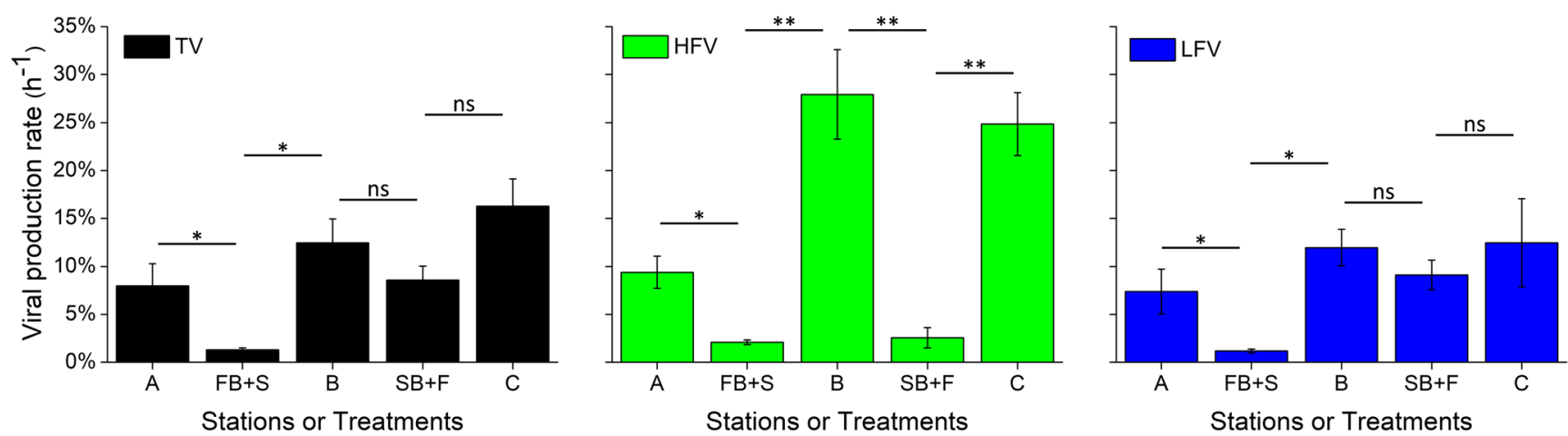

Fig. 3 The total virus (TV), high-fluorescence virus (HFV) and low-fluorescence virus (LFV) production rates in a cross-transplant experiment in PRE. Error bars are the standard errors of triplicate measurements. ns no significant difference; $* P<0.05 ; * * P<0.01$

These results indicated that the production rates of both riverine and marine viruses were inhibited by freshwater-seawater mixing. Furthermore, the production rates of the two viral subgroups followed the same pattern as the production rate of the total viruses. In the $\mathrm{FB}+\mathrm{S}$ treatment, the production rate was reduced from $9.40 \pm 1.68 \% \mathrm{~h}^{-1}$ (station A) to $2.09 \pm 0.24 \% \mathrm{~h}^{-1}$ for high-fluorescence viruses and from $7.39 \pm 2.34 \% \mathrm{~h}^{-1}$ (station A) to $1.18 \pm 0.21 \% \mathrm{~h}^{-1}$ for low-fluorescence viruses. Compared with the high- and low-fluorescence viral production rates $24.9 \pm 3.29 \mathrm{~h}^{-1}$ and $12.5 \pm 4.58 \mathrm{~h}^{-1}$, respectively, at station $\mathrm{C}$, the production rates in the $\mathrm{SB}+\mathrm{F}$ treatment were lower at $2.56 \pm 1.06 \% \mathrm{~h}^{-1}$ and $9.13 \pm 1.54 \%$, respectively.

These results suggested the production rates of the total riverine viruses were inhibited to a greater extent than were those of the marine viruses under freshwater-seawater mixing. However, the trends were opposite between the high- and low-fluorescence viruses. As observed for the total viruses, the low-fluorescence viruses showed greater inhibi-

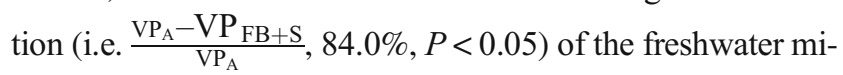
crobes added into seawater than of the seawater microbes added into freshwater (i.e. $\frac{\mathrm{VP}_{\mathrm{C}}-\mathrm{VP}_{\mathrm{SB}}+\mathrm{F}}{\mathrm{VP}_{\mathrm{C}}}, 26.8 \%$ ). In contrast, the high-fluorescence viruses showed weaker inhibition under the $\mathrm{FB}+\mathrm{S}$ treatment $(77.7 \%, P<0.05)$ than under the $\mathrm{SB}+\mathrm{F}$ treatment $(89.7 \%, P<0.01)$, suggesting that the effect of freshwater-seawater mixing on production rate differed between high- and low-fluorescence viruses.

In order to test the effect of brackish water on production rates of indigenous, riverine and marine viruses, the environmental conditions of the $\mathrm{FB}+\mathrm{S}$ and $\mathrm{SB}+\mathrm{F}$ treatments were both artificially adjusted to match those of the station B treatment (brackish water). Viral production rate significantly differed among the three treatments, being highest at station B (12.48 \pm $\left.2.46 \% \mathrm{~h}^{-1}\right)$, intermediate in the $\mathrm{SB}+\mathrm{F}$ treatment $(8.59 \pm$ $\left.1.46 \% \mathrm{~h}^{-1}\right)$ and lowest in the FB $+\mathrm{S}$ treatment $(1.29 \pm$ $0.20 \% \mathrm{~h}^{-1}$ ). The same trend also appeared when separately examining the high- and low-fluorescence viruses, with rates of $27.95 \pm 4.66 \% \mathrm{~h}^{-1}$ and $11.98 \pm 1.92 \% \mathrm{~h}^{-1}$, respectively, at station B; $2.56 \pm 1.06 \% \mathrm{~h}^{-1}$ and $9.13 \pm 1.54 \% \mathrm{~h}^{-1}$, respectively, in the
$\mathrm{SB}+\mathrm{F}$ treatment; and $2.09 \pm 0.24 \% \mathrm{~h}^{-1}$ and $1.18 \pm 0.21 \% \mathrm{~h}^{-1}$, respectively, in the $\mathrm{FB}+\mathrm{S}$ treatment. The results indicated that the simulated brackish water had different effects on production among the indigenous, riverine and marine viruses.

The effects of the freshwater-seawater cross-transplants on viral decay rate presented a pattern similar to that of their effects on viral production. Regardless of whether freshwater viruses were placed in seawater $(\mathrm{FV}+\mathrm{S}$ treatment) or seawater viruses were placed in freshwater $(\mathrm{SV}+\mathrm{F}$ treatment), viral decay rate declined, decreasing from $3.74 \pm 0.98 \% \mathrm{~h}^{-1}$ (station A) to $2.95 \pm 0.55 \% \mathrm{~h}^{-1}(\mathrm{FV}+\mathrm{S})$ and from $2.02 \pm 0.33 \% \mathrm{~h}^{-1}$ (station C) to $1.33 \pm 0.31 \% \mathrm{~h}^{-1}$ (SV $+\mathrm{F}$ ), respectively (Fig. 4). The decay rates of high- and low-fluorescence viruses showed the same trends as that of total viruses, indicating that the viral decay rates of total viruses and high- and low-fluorescence viruses were all inhibited by freshwater-seawater mixing.

Furthermore, the viral decay rate was reduced $21.1 \%$ for freshwater viruses placed in seawater and $34.2 \%$ for seawater viruses placed in freshwater, suggesting the viral decay of riverine viruses was inhibited slightly less than that of marine viruses under freshwater-seawater mixing. The decay rate of low-fluorescence viruses followed a similar pattern, with an inhibition of $12.8 \%$ under the $\mathrm{FV}+\mathrm{S}$ treatment and $21.1 \%$ under the SV + F treatment. However, the decay rate of highfluorescence viruses showed the opposite pattern, with stronger inhibition under the $\mathrm{FV}+\mathrm{S}$ treatment $(80.5 \%, P<0.05)$ than under the $\mathrm{SV}+\mathrm{F}$ treatment $(46.6 \%, P<0.05)$.

The environmental conditions of $\mathrm{FV}+\mathrm{S}$ and $\mathrm{SV}+\mathrm{F}$ were similar to those of station $\mathrm{B}$, and the results revealed significant differences in decay rate among indigenous, riverine and marine viruses. The viral decay rates, from large to small, were $2.95 \pm 0.55 \% \mathrm{~h}^{-1}$ under the $\mathrm{FV}+\mathrm{S}$ treatment, $1.33 \pm$ $0.33 \% \mathrm{~h}^{-1}$ under the $\mathrm{SV}+\mathrm{F}$ treatment and $0.80 \pm 0.23 \% \mathrm{~h}^{-1}$ at station B. These findings indicated that the simulated brackish water differentially affected the decay rates of indigenous, marine and riverine viruses. In addition, decay rate exhibited a different pattern between high- and low-fluorescence viruses. The highest decay rate of high-fluorescence viruses was detected in indigenous viruses $\left(2.81 \pm 0.31 \% \mathrm{~h}^{-1}\right)$, whereas 

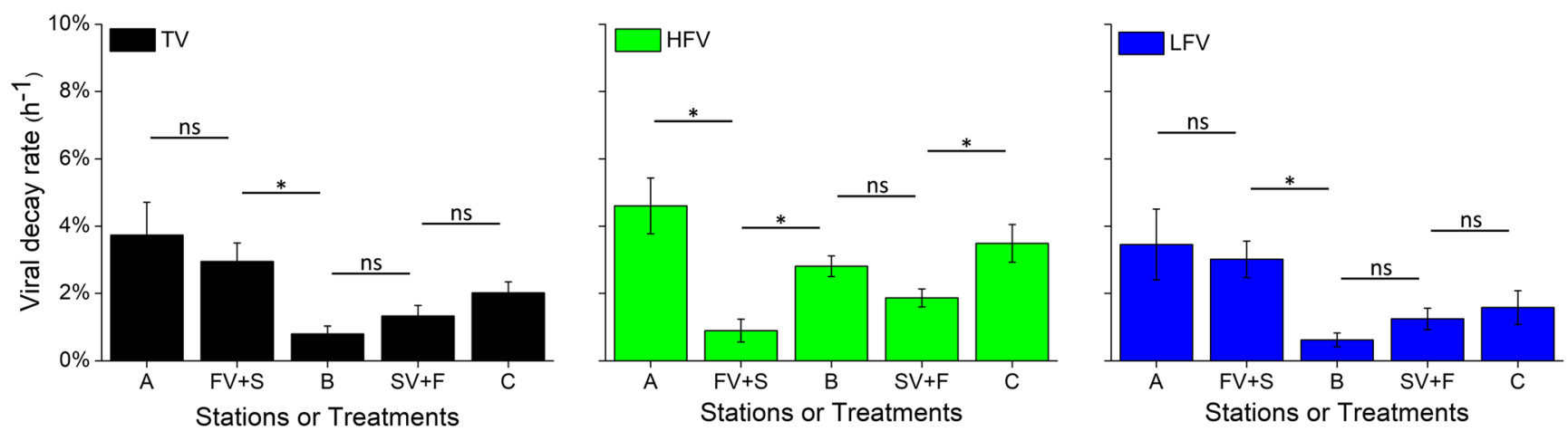

Fig. 4 The total virus (TV), high-fluorescence virus (HFV) and low-fluorescence virus (LFV) decay rates in a cross-transplant experiment in PRE. Error bars are the standard errors of triplicate measurements. ns no significant difference; $* P<0.05 ; * * P<0.01$

the lowest value for low-fluorescence viruses was found in indigenous viruses $\left(0.62 \pm 0.21 \% \mathrm{~h}^{-1}\right)$, indicating that the simulated brackish water differentially affected decay between high- and low-fluorescence viruses.

\section{Discussion}

In PRE, the heterotrophic bacterial, Synechococcus and picoeukaryotic abundances decreased with salinity in this investigation. This finding is consistent with previous studies in PRE and other tropical or subtropical estuaries [29, 32, 47, 48], indicating that salinity and inorganic and organic nutrients may be the dominant factors influencing the spatial distribution of picoplankton population size. In contrast, Prochlorococcus abundance increased with salinity, reflecting that the main habitat of Prochlorococcus is oceanic waters [47, 49].

The viral abundance, production rate and decay rate in PRE are similar to those reported in previous studies of estuarine environments (e.g. $[15,35])$. Different from the oligotrophic marine environment, an estuary receives large amounts of organic nutrients, which increase microbial abundance and enhance metabolic activity $[20,50]$. Thus, higher viral abundance and production and decay rates were observed in PRE compared with those reported for the open ocean. These findings indicate that viruses are highly dynamic and play important roles in the microbial ecology of the estuarine ecosystem $[28,35]$. However, the measurement of in situ viral parameters cannot reveal the underlying mechanism of their dynamics because of the mixing of different sources of the microbial and viral community (freshwater and seawater) in estuarine areas. For instance, compared to the continuous trend (increasing or decreasing) of picoplankton abundance, viral abundance and decay showed their minimum values in the brackish water area (station B) (Tables 1 and 2). This finding suggested that the underlying mechanisms controlling the dynamics of virioplankton and bacterioplankton differed among the different regimes of the estuary. Consequently, VPR, which is usually used as an indicator of virus-host interactions, varied in relatively small geographic scale. This suggested a loose coupling between virioplankton and their potential autotrophic and heterotrophic hosts in the PRE, probably due to the fact that viruses from river water are mixing with prokaryotes from marine water and vice versa. To further study the influential mechanism of the estuarine environment on viral particles and related viral process parameters, freshwater-seawater crosstransplants were performed in this study.

When the riverine and marine microbial communities were transferred into a simulated brackish water environment (i.e. $\mathrm{FB}+\mathrm{S}$ and $\mathrm{SB}+\mathrm{F}$ ), the production of viruses was markedly reduced (Fig. 3). Previous studies have reported that viral production is tightly related to the metabolism of their hosts, which is controlled by nutritional parameters, such as DOC and inorganic nutrients [51, 52]. This may explain the reduction of the viral production in the $\mathrm{FB}+\mathrm{S}$ treatment, in which the high DOC and nutrient concentrations were reduced via dilution with oligotrophic seawater, but it cannot explain the reduction in the SB + F treatment, in which the marine microbial hosts

Table 1 Microbial abundances at the three stations in PRE

\begin{tabular}{|c|c|c|c|c|c|c|c|}
\hline Station & $\begin{array}{l}\text { Het Bac } \\
\left(\times 10^{6} \text { cells ml }{ }^{-1}\right)\end{array}$ & $\begin{array}{l}\text { Syn } \\
\left(\times 10^{4} \text { cells } \mathrm{ml}^{-1}\right)\end{array}$ & $\begin{array}{l}\text { Pro } \\
\left(\times 10^{4} \text { cells } \mathrm{ml}^{-1}\right)\end{array}$ & $\begin{array}{l}\text { Euk } \\
\left(\times 10^{3} \text { cells } \mathrm{ml}^{-1}\right)\end{array}$ & $\begin{array}{l}\text { TV } \\
\left(\times 10^{6} \text { viruses } \mathrm{ml}^{-1}\right)\end{array}$ & $\begin{array}{l}\text { HFV } \\
\left(\times 10^{6} \text { viruses } \mathrm{ml}^{-1}\right)\end{array}$ & $\begin{array}{l}\text { LFV } \\
\left(\times 10^{6} \text { viruses } \mathrm{ml}^{-1}\right)\end{array}$ \\
\hline $\mathrm{A}$ & $4.33 \pm 0.11$ & $4.04 \pm 0.10$ & ND & $8.97 \pm 0.58$ & $27.5 \pm 1.07$ & $2.25 \pm 0.15$ & $25.3 \pm 1.25$ \\
\hline $\mathrm{B}$ & $1.58 \pm 0.24$ & $8.73 \pm 0.15$ & $0.97 \pm 0.05$ & $3.98 \pm 0.12$ & $2.72 \pm 0.09$ & $0.40 \pm 0.12$ & $2.33 \pm 0.08$ \\
\hline $\mathrm{C}$ & $0.88 \pm 0.09$ & $13.9 \pm 0.92$ & $16.1 \pm 0.42$ & $2.13 \pm 0.17$ & $3.83 \pm 0.20$ & $1.00 \pm 0.06$ & $2.83 \pm 0.14$ \\
\hline
\end{tabular}

Het Bac heterotrophic bacterial abundance, Syn Synechococcus abundance, Pro Prochlorococcus abundance, Euk picoeukaryotic abundance, TV total virus abundance, $H F V$ abundances of high-fluorescence viruses, $L F V$ abundances of low-fluorescence viruses, $N D$ not detected 
should have been provided more DOC and nutrients from the eutrophic waters. One possible explanation is that the carbon source and nutrient availability are not limiting factors for microbial activity in the brackish environment such that a "stimulation" effect of organic and inorganic nutrients on viral production was not observed in the $\mathrm{SB}+\mathrm{F}$ treatment. Environmental factors other than nutrients may regulate microbial activity and therefore the productivity of viral particles. Microbes are sensitive to changes in ionic strength, and an increase in salinity can weaken the physiological state of microbiological cells $[31,53]$. Studies have shown that seawater appears to have a strong inhibitory effect on riverine bacteria [54-56], whereas marine bacteria show high adaptability to variation in salinity [57]. In previous studies, seawater cause physiological stress on host metabolic processes [20, 54-56], which could include viral production, for infected cells, resulting in a decline of viral production. This mechanism can explain the stronger inhibition of viral production when the riverine microbes were transferred into seawater than when the marine microbes were transferred into freshwater. In addition, temperature is an important factor affecting viral production. In the cross-transplant experiment, the riverine and marine microbial communities were incubated at the in situ temperature of the brackish water environment, which was lower than the temperatures of their original environments (Table S1). Even a slight change of temperature can impact viral production through its regulation of the metabolic activity of the host microorganism [20]. Therefore, the large change in salinity and the decline in temperature might explain the inhibited viral production observed in both cross-transplant treatments. However, in order to elucidate the impact of individual parameter such as temperature or salinity on viral production and decay, further incubation experiments in field (e.g. with changing temperature but fixed salinity) and laboratory (based on isolated freshwater and marine phage-host system) are needed.

Our result showed the viral decay rates (total, high-, and lowfluorescence viruses) were inhibited when the riverine and marine viruses were transferred into simulated brackish water (Fig. 4). Compared to viral production, the decay of viral particles is considered to be more directly related to environmental factors [20]. Previous studies have shown that temperature is one of the most important factors affecting viral decay rate; it does so by directly damaging the biomolecular elasticity and molecular structure of proteins, such as membrane lipids and the protein capsids of viral particles [20]. For example, a positive correlation was obtained between the decay rate of Escherichia coli virus and temperature [18]. We previously found that warming significantly enhances the decay rates of viral communities in the western Pacific Ocean [21]. Therefore, in the experiment of freshwater-seawater cross-transplants, the inhibition of viral decay rate is partly explained by the lower in situ temperature at station B. Furthermore, changes in environmental factors (e.g. salinity and temperature) may decrease extracellular enzyme 
activity, which is another potential factor contributing to the inhibition. Extracellular enzymes (e.g. proteases and nucleases) are important factors affecting the viral decay rate by degrading viral protein capsids and the nucleic acids within [19, 22, 25]. Several studies have reported that the decay rate of viral particles is impacted by heat-labile substances, e.g. extracellular enzymes $[15,25,58]$. Low temperature may reduce enzyme activity through interference with the affinity of enzyme systems [59, $60]$. In addition, a change of ionic strength may also lead to the inhibition of extracellular enzyme activity. For example, the different extracellular enzymes have specific adaptations to salinity, such as $\beta$-glucosidase and proteases $[61,62]$. Thus, the decline of temperature and change of salinity in the treatments might have inhibited extracellular enzyme activity and resulted in the observed low viral decay rates. In addition, to maintain structural stability, bacteriophages appear to have specific ionic requirements, e.g. both $\mathrm{Na}^{+}$and $\mathrm{Mg}^{2+}$ are necessary for bacteriophages to maintain the activity and stability to infect their hosts $[63,64]$. Thus, changes in ionic strength might also have been important in accelerating the viral decay rate in the freshwater-seawater cross-transplants.

\section{High- vs. Low-Fluorescence Viruses}

When members of the marine microbial community were transferred into virus-free freshwater $(\mathrm{SB}+\mathrm{F})$, pronounced differences in the production of high- and low-fluorescence viruses were observed. Based on the production rates observed at station $\mathrm{C}$, the inhibition of high-fluorescence virus production $(89.7 \%$ ) was found to be stronger than that of lowfluorescence virus production (26.8\%) (Fig. 3), suggesting that the marine hosts of low-fluorescence viruses may be more adaptable to changes in environmental conditions than those of high-fluorescence viruses. A metagenomic analysis of flow-cytometry-sorted marine virioplankton suggested that the high-fluorescence viruses (having high nucleic acid content) were dominated by eukaryotic algal viruses, whereas the low-fluorescence viruses (having low nucleic acid content) were dominated by bacteriophages [65]. Therefore, the different effects of freshwater-seawater mixing on production between high- and low-fluorescence viruses suggest that marine prokaryotic bacteria may be more adaptable to changes in environmental condition (e.g. DOC, nutrients and salinity) than are marine algae.

Similarly, regardless of whether members of the riverine viral community or marine viral community were transferred into brackish-like water $(\mathrm{FV}+\mathrm{S}$ and $\mathrm{SV}+\mathrm{F})$, the effects on decay rate were markedly different between the high- and low-fluorescence viruses. The inhibition of highfluorescence viral decay rate was stronger than that of lowfluorescence viral decay rate $(80.5 \%$ and $46.6 \%$ vs. $12.8 \%$ and $21.1 \%$ ). Based on the above discussion, this result suggests that algal viruses have more resistance to decay than do bacteriophages when transferred into simulated brackish water. Previous studies have shown that the viral decay rate increases significantly with the density of the packaged nucleic acid material of viruses [18]. Compared to bacteriophages, algal viruses typically have a lower density of packaged nucleic acid material $[18,21]$. Therefore, when encountering rapid environmental changes such as a change in osmotic pressure, the capsid of bacteriophages seems to be more easily destroyed by internal pressure caused by the bending of nucleic acids and the strong repulsion between the highly charged neighbouring nucleic acid segments [66, 67]. This mechanism can explain why the nonindigenous lowfluorescence viruses showed higher decay rates than did the indigenous ones, with the bacteriophages being more prone to decay following a change of salinity. However, in contrast, the nonindigenous high-fluorescence virus decay rates were lower than indigenous ones, suggesting the algal viruses may be more prone to decay due to extracellular enzymes than to changes in salinity.

\section{Viruses in Brackish Waters}

The freshwater-seawater cross-transplants showed that in situ viral production and decay at station $\mathrm{B}$ were different than they were under the $\mathrm{FB} / \mathrm{V}+\mathrm{S}$ and $\mathrm{SB} / \mathrm{V}+\mathrm{F}$ treatments. This result suggests that the mixing of nonindigenous hosts and viruses between the upstream river and downstream sea alone cannot veritably explain the in situ viral dynamics in brackish waters. Therefore, we hypothesised that brackish waters of PRE may harbour indigenous hosts and their viruses, which were supported by molecular ecology studies in other estuarine systems $[68,69]$. In addition, compared with the in situ viral production and decay rates in brackish water, the nonindigenous viral production values (i.e. riverine and marine production values) were lower, but the nonindigenous viral decay rates were higher. These findings suggested a higher production rate and a lower decay rate of indigenous viruses of brackish water. However, this needs more experiments using the isolated viruses in laboratory or virus communities in natural environments to confirm. In addition, $\operatorname{VMM}\left(=\frac{\Delta \mathrm{PA}}{\mathrm{PA}_{0}}\right)$ and $\mathrm{CRL}(=\Delta \mathrm{PA} \times 12.4 \mathrm{fg})$ are directly related to $\triangle \mathrm{PA}$ during incubation period, which may be overestimated since some nonindigenous prokaryotic bacteria are not suitable to survive in brackish water environment, resulting in death. But they were significantly higher in the brackish water than in the freshwater and seawater. This may indicate that viruses are important in mediating the carbon cycle and biogeochemical cycles via the viral shunt in brackish water areas.

An interesting observation is that the lowest viral population size (abundance) together with high in situ viral production and the lowest in situ viral decay rate were observed in 
brackish water. This finding indicated the possible overestimation of viral production or possible underestimation of viral decay from the in situ measurements. According to the experimental design used for viral production measurement, the estimation considered viral particles produced on particles less than $3 \mu \mathrm{m}$ in diameter (as the water samples were pre-filtered with $3-\mu \mathrm{m}$ filters). However, due to the $0.22-\mu \mathrm{m}$ filtration, the estimation of viral decay excluded all particles that can adsorb viral particles and protozoa that can passively graze them. Station B, in the brackish water area, receives large amounts of organic and inorganic particles, which may have caused the overestimation of viral production or the underestimation of viral decay. In addition, the adsorption of large numbers of viruses by organic and inorganic particles in the brackish water area may be an important route by which the carbon and other elements of viral particles sink into the sediment.

\section{Conclusions}

As important members of marine ecosystems, viruses affect the microbial ecology and biogeochemical cycles of the marine environment by releasing DOC and nutrients into the environment by host lysis and the decay of viral particles. Our study showed complex viral ecological dynamics in a typical estuary area based on in situ observations and a freshwater-seawater cross-transplant experiment. The results showed that the mixing of freshwater and seawater caused decreases in viral production and decay rates, indicating that changes in environmental factors, such as temperature, salinity, DOC and nutrients, due to freshwater-seawater mixing impact the ecological behaviours of virioplankton in the estuary. Furthermore, the high- and low-fluorescence viruses showed different responses to water mixing. Together, these findings improve our knowledge of the ecological dynamics of viruses in the estuarine environment and our understanding of microbial ecology in complex estuary ecosystems.

Acknowledgments The authors wish to thank Jianning Wang, Wei Xiao and Zhao Zhao for their assistance with the sampling.

Funding Information This work was supported by the projects of National Natural Science Foundation of China (41522603, 31570172, 91428308, 41673073 and 41861144018). Rui Zhang was partially supported by Qingdao National Laboratory for Marine Science and Technology (QNLM2016ORP0303). The authors thank the captains and crews of the RV KEXUE for their excellent support during the cruise (KEXUE2017G14).

Open Access This article is distributed under the terms of the Creative Commons Attribution 4.0 International License (http:// creativecommons.org/licenses/by/4.0/), which permits unrestricted use, distribution, and reproduction in any medium, provided you give appropriate credit to the original author(s) and the source, provide a link to the Creative Commons license, and indicate if changes were made.

\section{References}

1. Bergh Ø, Børsheim KY, Bratbak G, Heldal M (1989) High abundance of viruses found in aquatic environments. Nature 340:467468. https://doi.org/10.1038/340467a0

2. Suttle CA (2007) Marine viruses - major players in the global ecosystem. Nat Rev Microbiol 5:801-812. https://doi.org/10.1038/ nrmicro 1750

3. Fuhrman JA (1999) Marine viruses and their biogeochemical and ecological effects. Nature 399:541-548. https://doi.org/10.1038/ 21119

4. Weinbauer MG (2004) Ecology of prokaryotic viruses. FEMS Microbiol. Rev. 28:127-181. https://doi.org/10.1016/j.femsre. 2003.08.001

5. Suttle CA (2005) Viruses in the sea. Nature 437:356-361. https:// doi.org/10.1038/nature04160

6. Jiao N, Herndl GJ, Hansell DA, Benner R, Kattner G, Wilhelm SW, Kirchman DL, Weinbauer MG, Luo T, Chen F, Azam F (2010) Microbial production of recalcitrant dissolved organic matter: long-term carbon storage in the global ocean. Nat Rev Microbiol 8:93-99. https://doi.org/10.1038/nrmicro2386

7. Noble RT, Fuhrman JA (2000) Rapid virus production and removal as measured with fluorescently labeled viruses as tracers. Appl Environ Microb 66:3790-3797. https://doi.org/10.1128/aem.66.9. 3790-3797.2000

8. Weinbauer MG, Brettar I, Höfle MG (2003) Lysogeny and virusinduced mortality of bacterioplankton in surface, deep, and anoxic marine waters. Limnol. Oceanogr. 48:1457-1465. https://doi.org/ 10.4319/lo.2003.48.4.1457

9. van Hannen EJ, Zwart G, vav Agterveld MP, Gons HJ, Ebert J, Laanbroek HJ (1999) Changes in bacterial and eukaryotic community structure after mass lysis of filamentous cyanobacteria associated with viruses. Appl Environ Microb 65:795-801

10. Jover LF, Effler TC, Buchan A, Buchan A, Wilhelm SW, Weitz JS (2014) The elemental composition of virus particles: implications for marine biogeochemical cycles. Nat Rev Microbiol 12:519-528. https://doi.org/10.1038/nrmicro3289

11. Zhang R, Wei W, Cai L (2014) The fate and biogeochemical cycling of viral elements. Nat Rev Microbiol 12:850-851. https://doi.org/ 10.1038/nrmicro3384

12. Glud R, Middelboe M (2004) Virus and bacteria dynamics of a coastal sediment: implication for benthic carbon cycling. Limnol. Oceanogr. 49:2073-2081. https://doi.org/10.4319/lo.2004.49.6. 2073

13. Mei ML, Danovaro R (2004) Viral production and life strategies in aquatic sediments. Limnol. Oceanogr. 49:459-470. https://doi.org/ 10.4319/lo.2004.49.2.0459

14. Parada V, Sintes E, van Aken HM, Weinbauer MG, Herndl GJ (2007) Viral abundance, decay, and diversity in the meso- and bathypelagic waters of the North Atlantic. Appl Environ Microb 73:4429-4438. https://doi.org/10.1128/aem.00029-07

15. Bongiorni L, Magagnini M, Armeni M, Noble R, Danovaro R (2005) Viral production, decay rates, and life strategies along a trophic gradient in the North Adriatic Sea. Appl Environ Microb 71:6644-6650. https://doi.org/10.1128/aem.71.11.6644-6650.2005

16. Li Y, Luo T, Sun J, Cai L, Liang Y, Jiao N, Zhang R (2014) Lytic viral infection of bacterioplankton in deep waters of the western pacific ocean. Biogeosciences 11:2531-2542. https://doi.org/10. 5194/bg-11-2531-2014

17. Wommack KE, Colwell RR (2000) Virioplankton: viruses in aquatic ecosystems. Microbiol. Mol. Biol. Rev. 64:69-114. https://doi. org/10.1128/mmbr.64.1.69-114.2000

18. de Paepe M, Taddei F (2006) Viruses' life history: towards a mechanistic basis of a trade-off between survival and reproduction 
among phages. PLoS Biol. 4:1248-1256. https://doi.org/10.1371/ journal.pbio.0040193

19. Danovaro R, Dell'Anno A, Corinaldesi C, Magagnini M, Noble R, Tamburini C, Weinbauer M (2008) Major viral impact on the functioning of benthic deep-sea ecosystems. Nature 454:1084-1087. https://doi.org/10.1038/nature07268

20. Mojica KD, Brussaard CP (2014) Factors affecting virus dynamics and microbial host-virus interactions in marine environments. FEMS Microbiol. Ecol. 89:495-515. https://doi.org/10.1111/ 1574-6941.12343

21. Wei W, Zhang R, Peng L, Liang Y, Jiao N (2018) Effects of temperature and photosynthetically active radiation on virioplankton decay in the western Pacific Ocean. Sci. Rep. 8(1525):1525. https://doi.org/10.1038/s41598-018-19678-3

22. Suttle CA, Chen F (1992) Mechanisms and rates of decay of marine viruses in seawater. Appl Environ Microb 58:3721-3729

23. Weinbauer MG, Fuks D, Peduzzi P (1993) Distribution of viruses and dissolved DNA along a coastal trophic gradient in the Northern Adriatic Sea. Appl Environ Microb 59:4074-4082

24. Fuhrman JA, Noble RT (1995) Viruses and protists cause similar bacterial mortality in coastal seawater. Limnol. Oceanogr. 40:12361242. https://doi.org/10.4319/lo.1995.40.7.1236

25. Noble RT, Fuhrman JA (1997) Virus decay and its causes in coastal waters. Appl Environ Microb 63:77-83

26. Bernhard AE, Donn T, Giblin AE, Stahl DA (2005) Loss of diversity of ammonia-oxidizing bacteria correlates with increasing salinity in an estuary system. Environ. Microbiol. 7:1289-1297. https:// doi.org/10.1111/j.1462-2920.2005.00808.x

27. Kirchman DL, Dittel AI, Malmstrom RR, Cottrell MT (2005) Biogeography of major bacterial groups in the Delaware Estuary. Limnol. Oceanogr. 50:1697-1706. https://doi.org/10.4319/lo.2005. 50.5.1697

28. Xu J, Jing H, Kong L, Sun M, Harrison PJ, Liu H (2013) Effect of seawater-sewage cross-transplants on bacterial metabolism and diversity. Microb. Ecol. 66:60-72. https://doi.org/10.1007/s00248013-0207-2

29. Cissoko M, Desnues A, Bouvy M, Sime-Ngando T, Verling E, Bettarel Y (2008) Effects of freshwater and seawater mixing on virio- and bacterioplankton in a tropical estuary. Freshw. Biol. 53: 1154-1162. https://doi.org/10.1111/j.1365-2427.2007.01930.x

30. Bettarel Y, Bouvier T, Agis M, Bouvier C, Chu TV, Combe M, Mari $X$, Nghiem MN, Nguyen TT, Pham TT, Pringault O, RochelleNewall E, Torréton J, Tran HQ (2011) Viral distribution and life strategies in the Bach Dang Estuary, Vietnam. Microb. Ecol. 62: 143-154. https://doi.org/10.1007/s00248-011-9835-6

31. Bettarel Y, Bouvier T, Bouvier C, Carré C, Desnues A, Domaizon I, Jacquet S, Robin A, Sime-Ngando T (2011) Ecological traits of planktonic viruses and prokaryotes along a full-salinity gradient. FEMS Microbiol. Ecol. 76:360-372. https://doi.org/10.1111/j. 1574-6941.2011.01054.x

32. Ni Z, Huang X, Zhang X (2015) Picoplankton and virioplankton abundance and community structure in Pearl River Estuary and Daya Bay, South China. J. Environ. Sci. (China) 32:146-154. https://doi.org/10.1016/j.jes.2014.12.019

33. Winget DM, Helton RR, Williamson KE, Bench SR, Williamson SJ, Wommack KE (2011) Repeating patterns of virioplankton production within an estuarine ecosystem. Proc. Natl. Acad. Sci. U. S. A. 108:11506-11511. https://doi.org/10.1073/pnas.1101907108

34. He L, Yin K, Yuan X, Li D, Zhang D, Harrison PJ (2009) Spatial distribution of viruses, bacteria and chlorophyll in the northern South China Sea. Aquat. Microb. Ecol. 54:153-162. https://doi. org/10.3354/ame01263

35. Chen X, Liu H, Weinbauer M, Chen B, Jiao N (2011) Viral dynamics in the surface water of the western South China Sea in summer 2007. Aquat. Microb. Ecol. 63:145-160. https://doi.org/10.3354/ ame 01490
36. Xu J, Jing H, Sun M, Harrison PJ, Liu H (2014) Regulation of bacterial metabolic activity by dissolved organic carbon and viruses. J Geophys Res-Biogeo 118:1573-1583. https://doi.org/10.1002/ 2013jg002296

37. Wen K, Ortmann AC, Suttle CA (2004) Accurate estimation of viral abundance by epifluorescence microscopy. Appl Environ Microb 70:3862-3867. https://doi.org/10.1128/aem.70.7.3862-3867.2004

38. Marie D, Partensky F, Vaulot D, Brussaard C (1999) Numeration of phytoplankton, bacteria and viruses in marine samples. Curr Protocols Cytom 11:1-15. https://doi.org/10.1002/0471142956. cy1111s10

39. Liang Y, Li L, Luo T, Zhang Y, Zhang R, Jiao N (2014) Horizontal and vertical distribution of marine virioplankton: a basin scale investigation based on a global cruise. PLoS One 9:e111634. https:// doi.org/10.1371/journal.pone.0111634

40. Marie D, Brussaard CPD, Thyrhaug R, Bratbak G, Vaulot D (1999) Enumeration of marine viruses in culture and natural samples by flow cytometry. Appl Environ Microb 65:45-52

41. Brussaard CP (2004) Optimization of procedures for counting viruses by flow cytometry. Appl Environ Microb 70:1506-1513. https://doi.org/10.1128/aem.70.3.1506-1513.2004

42. Winget DM, Williamson KE, Helton RR, Wommack KE (2005) Tangential flow diafiltration: an improved technique for estimation of virioplankton production. Aquat. Microb. Ecol. 41:221-232. https://doi.org/10.3354/ame041221

43. Weinbauer M, Rowe J, Wilhelm S (2010) Determining rates of virus production in aquatic systems by the virus reduction approach. Manual of aquatic viral ecology, pp 1:1-1:8. https://doi. org/10.4319/mave.2010.978-0-9845591-0-7.1

44. Wilhelm S, Brigden S, Suttle C (2002) A dilution technique for the direct measurement of viral production: a comparison in stratified and tidally mixed coastal waters. Microb. Ecol. 43:168-173. https:// doi.org/10.1007/s00248-001-1021-9

45. Luef B, Luef F, Peduzzi P (2009) Online program 'vipcal' for calculating lytic viral production and lysogenic cells based on a viral reduction approach. Environ. Microbiol. Rep. 1:78-85. https://doi. org/10.1111/j.1758-2229.2008.00008.x

46. Fukuda R, Ogawa H, Nagata T, Koike I (1998) Direct determination of carbon and nitrogen contents of natural bacterial assemblages in marine environments. Appl Environ Microb 64:33523358

47. Zhang X, Shi Z, Ye F, Zeng Y, Huang X (2013) Picophytoplankton abundance and distribution in three contrasting periods in the Pearl River Estuary, South China. Mar. Freshw. Res. 64:692-705. https:// doi.org/10.1071/mf12303

48. Tsai AY, Gong GC, Huang YW, Huang YW, Chao CF (2015) Estimates of bacterioplankton and Synechococcus spp. mortality from nanoflagellate grazing and viral lysis in the subtropical Danshui River estuary. Estuar Coast Shelf Sci 153:54-61. https:// doi.org/10.1016/j.ecss.2014.11.032

49. Jochem FJ (2003) Photo- and heterotrophic pico- and nanoplankton in the Mississippi River plume: distribution and grazing activity. J. Plankton Res. 25:1201-1214. https://doi.org/10.1093/plankt/ fbg087

50. Danovaro R, Corinaldesi C, Dell'Anno A, Fuhrman JA, Middelburg JJ, Noble RT, Suttle CA (2011) Marine viruses and global climate change. FEMS Microbiol. Rev. 35:993-1034. https://doi.org/10.1111/j.1574-6976.2010.00258.x

51. Steward GF, Wikner J, Cochlan WP, Smith DC, Azam F (1992) Estimation of virus production in the sea. II: field results. Marine Microbial Food Webs 6:79-90

52. Grieg FS, Smith C, Azam F (1996) Abundance and production of bacteria and viruses in the Bering and Chukchi seas. Mar. Ecol. Prog. Ser. 131:287-300. https://doi.org/10.3354/meps131287 
53. Kukkaro P, Bamford DH (2009) Virus-host interactions in environments with a wide range of ionic strengths. Environ. Microbiol. Rep. 1:71-77. https://doi.org/10.1111/j.1758-2229.2008.00007.x

54. Painchaud J, Lefaivre D, Therriault JC, Legendre L (1995) Physical processes controlling bacterial distribution and variability in the upper St. Lawrence estuary. Estuaries 18:433-444. https://doi.org/ $10.2307 / 1352362$

55. del Giorgio PA, Bouvier T (2002) Linking the physiologic and phylogenetic successions in free-living bacterial communities along an estuarine salinity gradient. Limnol. Oceanogr. 47:471-486. https://doi.org/10.4319/lo.2002.47.2.0471

56. Troussellier M, Schäfer H, Batailler N, Bernard L, Courties C, Lebaron P, Muyzer G, Servais P, Vives-Rego J (2002) Bacterial activity and genetic richness along an estuarine gradient (Rhone River plume, France). Aquat. Microb. Ecol. 28:13-24. https://doi. org/10.3354/ame028013

57. Forsyth MP, Shindler DB, Gouchnauer MB, Kushner DJ (1971) Salt tolerance of intertidal marine bacteria. Can J Microbio 17: 825-828. https://doi.org/10.1139/m71-133

58. Dell'anno A, Corinaldesi C, Danovaro R (2015) Virus decomposition provides an important contribution to benthic deep-sea ecosystem functioning. Proc. Natl. Acad. Sci. U. S. A. 112:e2014-e2019. https://doi.org/10.1073/pnas.1422234112

59. Zweifel UL (1999) Factors controlling accumulation of labile dissolved organic carbon in the Gulf of Riga. Estuar Coast Shelf S 48: 357-370. https://doi.org/10.1006/ecss.1998.0428

60. Pomeroy LR, Wiebe WJ (2001) Temperature and substrates as interactive limiting factors for marine heterotrophic bacteria. Aquat. Microb. Ecol. 23:187-204. https://doi.org/10.3354/ame023187
61. Hoppe HG, Gocke K, Alcántara F (1996) Shifts between autotrophic and heterotrophic processes in a tidal lagoon (Ria de Aveiro, Portugal). Arch. Hydrobiol. 48:39-52

62. Cunha MA, Almeida MA, Alcântara F (2000) Patterns of ectoenzymatic and heterotrophic bacterial activities along a salinity gradient in a shallow tidal estuary. Mar. Ecol. Prog. Ser. 204:1-12. https://doi.org/10.3354/meps204001

63. Chen PK, Citarella RV, Salazar O, Colwell RR (1966) Properties of two marine bacteriophages. J. Bacteriol. 91:1136-1139

64. Keynan A, Nealson K, Sideropoulos H, Hastings JW (1974) Marine transducing bacteriophage attacking a luminous bacterium. J. Virol. 14:333-340

65. Martínez JM, Swan BK, Wilson WH (2014) Marine viruses, a genetic reservoir revealed by targeted viromics. ISME J 8:10791088. https://doi.org/10.1038/ismej.2013.214

66. Kindt J, Tzlil S, Ben-Shaul A, Gelbart WM (2001) DNA packaging and ejection forces in bacteriophage. Proc. Natl. Acad. Sci. U. S. A. 98:13671-13674. https://doi.org/10.1073/pnas.241486298

67. Evilevitch A, Castelnovo M, Knobler CM, Gelbart WM (2004) Measuring the force ejecting DNA from phage. J. Phys. Chem. B 108:6838-6843. https://doi.org/10.1021/jp0376525

68. Cai L, Zhang R, He Y, Feng X, Jiao N (2016) Metagenomic analysis of virioplankton of the subtropical Jiulong River Estuary, China. Viruses 8:35-48. https://doi.org/10.3390/v8020035

69. Liu L, Cai L, Zhang R (2017) Co-existence of freshwater and marine T4-like myoviruses in a typical subtropical estuary. FEMS Microbiol. Ecol. 93:1-9. https://doi.org/10.1093/femsec/fix119 